\title{
Did Austerity Cause Brexit? Evidence from Aggregate Trends in Euroscepticism
}

\author{
Noah Carl* \\ $23^{\text {rd }}$ September, 2018
}

\begin{abstract}
Fetzer (2018) presents evidence from analyses of panel data at the constituency and individual levels, which suggest that austerity measures implemented by the Conservative-led Coalition government may have caused an increase in the Leave vote share by up to 9.5 percentage points. If Fetzer's hypothesis were correct, one would expect aggregate Euroscepticism to increase after 2010, during the period of austerity. However, analyses of three separate polling series suggest the opposite, namely that aggregate Euroscepticism declined between 2010 and 2015. A plausible interpretation of this finding is that Euroscepticism peaked around the time of the Eurozone debt crisis, and was not strongly affected by austerity.
\end{abstract}

Key words: Brexit, austerity, Euroscepticism, voting

* Independent researcher, UK: noah_car13742@hotmail.com 


\section{Introduction}

In an interesting recent paper, Fetzer (2018) presents evidence from analyses of panel data at the constituency and individual levels, which suggest that austerity measures implemented by the Conservative-led Coalition government may have caused an increase in the Leave vote share by up to 9.5 percentage points. Specifically, he analyses data from the local, European and Westminster elections, and shows that constituencies hit by larger austerity shocks after 2010 saw bigger increases in the UKIP vote share. He also analyses individual level data from the British Household Panel Survey, and shows that individuals affected by larger austerity shocks after 2010 were more likely to express support for UKIP. All his models control for fixed effects, meaning that they only exploit within-constituency or within-individual variation. Based on the fact that support for UKIP is a strong predictor of voting Leave at both the constituency and individual levels, Fetzer concludes that austerity may have led to an increase in the Leave vote share by up to 9.5 percentage points, an amount more than large enough to flip the referendum result. The causal mechanism Fetzer postulates to explain these putative effects is that UKIP convinced a large number of people with austerity-induced anti-establishment grievances to engage in a major protest vote against the country's political elites, particularly those within the Conservative Party (pp. 4-5, p.10, p. 35).

While Fetzer (2018) deserves credit for a highly creative and thorough analysis, his paper has already been subjected to a number of criticisms. McKay and Bailey (2018) argue that austerity did not necessarily have a causal impact on UKIP vote share at all, insofar as people with a latent propensity to vote UKIP were more likely to be affected by austerity, and the implementation of austerity happened to occur at the time that UKIP changed its electoral strategy toward winning over such people. In particular, UKIP went from targeting middleclass Conservative voters (who were relatively unaffected by austerity) to targeting working-class Conservative and Labour voters (who were much more likely to be affected by austerity). It did so by re-focussing its core message on the dangers of mass immigration, and by introducing policies such as investment in the manufacturing sector, as well as tougher sentences for criminals (Ford and Goodwin, 2014, Ch. 2). Note that there is a large body of evidence showing that working-class people are more likely to hold socially conservative, nationalist and anti-immigration attitudes (Evans and Carl, 2017).

Lai (2018) argues that if voters who defected to UKIP after 2010 had been primarily motivated by austerity-induced anti-establishment grievances (as opposed to genuine Euroscepticism and opposition to immigration), then they would have defected to the Greens, an anti-establishment party that was far more opposed to austerity than UKIP. Indeed as Lai (2018) points out, UKIP's 2015 manifesto included a number of policies that arguably constitute rather severe austerity measures, such as 'Supporting a lower cap on benefits', 'Cracking down on benefit fraud', and 'Limiting child benefit to two children for new claimants' (UKIP, 2015). Another point Lai (2018) makes is that when the UKIP vote share collapsed at the 2017 election, a large fraction of their voters went back to the Conservatives, even though Labour was then being led by Jeremy Corbyn, an anti-establishment figure with a long record of opposing austerity. According to Kellner (2017), 46\% of those who voted UKIP in 2015 went for the Conservatives in 2017, whereas only 12\% went for Labour. This again suggests that most UKIP voters were motivated by genuine Euroscepticism and opposition to immigration, rather than by austerity-induced anti-establishment grievances. 
Furthermore, Fetzer's argument is inconsistent with surveys of people's stated reasons for voting Leave. Before the referendum took place, the British Election Study team asked their respondents an openended question, namely 'What matters most to you when deciding how to vote in the EU referendum?' (Prosser et al., 2016). They coded the responses into 54 categories encompassing the main concerns that respondents mentioned. By far the most frequently cited concerns among Leave supporters were 'sovereignty/EU bureaucracy' and 'immigration'. Moreover, researchers at the Centre for Social Investigation asked Leave voters to rank four reasons for voting Leave in order of how important they were when deciding which way to vote in the referendum (Carl, 2018). The two most important reasons were 'to regain control over EU immigration' and 'didn't want the EU to have any role in UK law-making'. And by far the least important reason, ranked fourth by $88 \%$ of respondents, was 'to teach British politicians a lesson'. Finally, in a forthcoming paper, Carl et al. (2018) show that measures of austerity and inequality are not strongly related to Euroscepticism across EU member states. ${ }^{1}$

In addition to the limitations mentioned above, another obvious weakness of Fetzer's analysis is that he relies on UKIP support as a proxy for Euroscepticism. Although these two variables are strongly related at both the constituency and individual levels, they are not identical constructs. Most importantly, as McKay and Bailey (2018) point out, the fact that UKIP's vote share was low prior to 2013 does not imply that Eurosceptic sentiment was then largely absent from the population. In this vein, the present paper tests a corollary of Fetzer's argument, namely that the implementation of austerity measures should coincide with a rise in aggregate Euroscepticism. As Fetzer notes (see his Figure 4), the Conservative-led Coalition government began reducing per-capita spending on welfare, education and healthcare in fiscal year 2010-11. Per capita spending on welfare and education continued to decrease until at least 2015. Hence if Fetzer's hypothesis were correct, one would expect aggregate Euroscepticism to increase after 2010.

\section{Method}

Three separate polling series were examined. The first was the series conducted by Ipsos MORI (2016), which begins in 1977 and ends in 2016. ${ }^{2}$ The specific question asked was, 'If there were a referendum now on whether Britain should stay in or get out of the European Union, how would you vote?' The response categories were 'Stay in', 'Get out', and 'Don't know'. Polls were averaged within years, and aggregate Euroscepticism was computed as the percentage saying 'Get out' minus the percentage saying 'Stay in'. The second polling series was the one conducted by the European Commission (2016) and the European Parliament (2016). This series corresponds to the Eurobarometer survey between 1973 and 2011, and to the Parlemeter between 2012 and 2016. The specific question asked was, 'Generally speaking, do you think that our country's membership of the EU is...?' The response categories were 'A good thing', 'A bad thing', 'Neither a good thing nor a bad thing', and 'Don't know'. Polls were averaged within years, and aggregate Euroscepticism was computed as the percentage saying 'Bad thing' minus the percentage saying 'Good thing'. The third polling series was the one conducted by YouGov (2016), which begins in 2010 and ends in 2016. The specific question asked was,

\footnotetext{
${ }^{1}$ Although some austerity-stricken countries like Greece and Italy now show high levels of Euroscepticism, others such as Ireland and Spain continue to show low levels of Euroscepticism.

${ }^{2}$ Note that there were missing values in the following years: 1982, 1985-86, 1988, 1995, 2002, 2004-06, 2008-10, and 2013.
} 
'Should the United Kingdom remain a member of the European Union or leave the European Union?' The response categories were 'Remain', 'Leave', 'Wouldn't vote' and 'Don't know'. Once again, polls were averaged within years, and aggregate Euroscepticism was computed as the percentage saying 'Leave' minus the percentage saying 'Remain'.

\section{Results}

As Table 1 shows, the three series are strongly correlated with one another. Given that they were taken from entirely independent sources, and each one corresponds to a slightly different question, this provides rather strong evidence that they are tapping into an underlying dimension of Euroscepticism.

Table 1. Correlations between measures of Euroscepticism.

\begin{tabular}{lccc}
\hline & Ipsos MORI & Eurobarometer & YouGov \\
\hline Ipsos MORI & 1 & & \\
Eurobarometer & $.91^{* * *}$ & 1 & 1 \\
YouGov & $.95^{*}$ & $.89^{* *}$ & 1 \\
\hline
\end{tabular}

Notes: For Ipsos MORI $\times$ Eurobarometer, $n=27$. For Ipsos MORI $\times$ YouGov, $n=5$. And for Eurobarometer $\times$ YouGov, $n=$ 7. Significance levels: $* 5 \%, * * 1 \%, * * * 0.1 \%$.

Figure 1 plots the three polling series over time. The Ipsos MORI series and the Eurobarometer series both trend upward from 1991 to 2011, and then trend downward from 2011 to 2015. The YouGov series fluctuates up and down between 2010 and 2012, and then trends downward from 2012 to 2015. All three series exhibit an uptick from 2015 to 2016.

Figure 1. Three polling series of Euroscepticism.

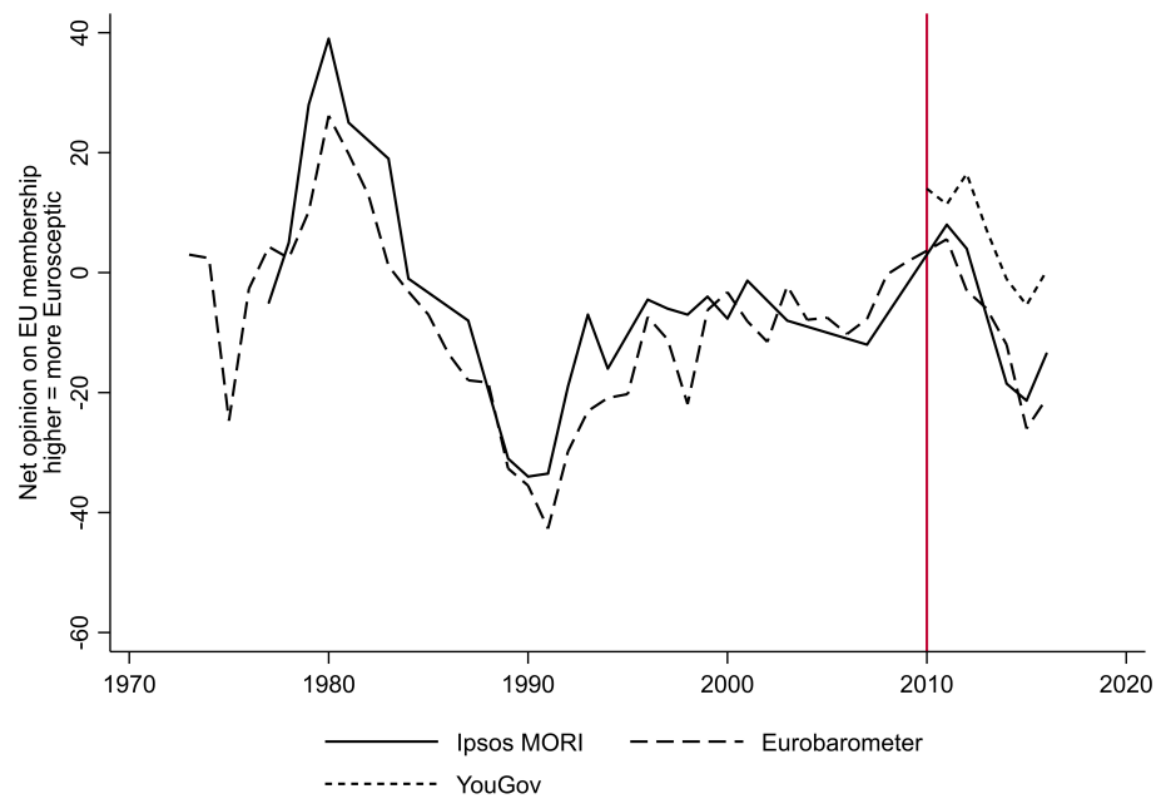

Notes: The red line indicates the beginning of austerity under the Conservative-led coalition government. 
It is important to note that the Ipsos MORI series is interpolated between 2007 and 2011, as well as between 2012 and 2014. In addition, the YouGov value for 2010 is based on only a single poll. Table 2 shows the number of polls that each yearly value is based on, for the period 2007-2016. The figures in Table 2 indicate that more information is available about the level of Euroscepticism for the period 2011-2016 than about the level of Euroscepticism for the period from 2007-2010. However, polls from two of the three series were at least available for the years 2007 and 2010 .

Table 2. Number of polls that each yearly value is based on, for the three polling series.

\begin{tabular}{cccc}
\hline Year & Ipsos MORI & Eurobarometer & YouGov \\
\hline 2007 & 1 & 1 & $\cdot$ \\
2008 & $\cdot$ & 1 & $\cdot$ \\
2009 & $\cdot$ & 1 & $\cdot$ \\
2010 & $\cdot$ & 1 & 5 \\
2011 & 1 & 1 & 12 \\
2012 & 1 & 1 & 24 \\
2013 &. & 1 & 29 \\
2014 & 2 & 1 & 15 \\
2015 & 3 & 1 & 25 \\
\hline
\end{tabular}

Notes: Dots indicate missing data.

The three series were averaged in order to obtain an overall measure of Euroscepticism. Prior to averaging, each series was adjusted so that it took the value 0 in 2016. In other words, 13.5 was added to each value in the Ipsos MORI series, 21 was added to each value in the Eurobarometer series, and 0.28 was subtracted from each value in the YouGov series. This ensured that average Euroscepticism would take the value 0 in the year 2016. Figure 2 plots average Euroscepticism over time. ${ }^{3}$ The series trends upwards from 1991 to 2009, and then trends downward from 2009 to 2015. It exhibits an uptick from 2015 to 2016. The decline from 2011 to 2015 is monotonic. Prima facie, this is inconsistent with what one would expect on the basis of Fetzer's hypothesis. A plausible interpretation of the preceding results is that Euroscepticism peaked around the time of the Eurozone debt crisis (Braun and Tausendpfund, 2014), and was not strongly affected by austerity. ${ }^{4}$

\footnotetext{
${ }^{3}$ The plot was almost identical when using a weighted average of the three series with weights corresponding to squarerooted numbers of polls (see Stata code in the Supporting Information). Indeed, the weighted average and the unweighted average were correlated at $r=.999(p<0.001)$ for the whole time period, and at $r=.994(p<0.001)$ for the period 20072016.

${ }^{4}$ In their forthcoming paper, Carl et al. (2018) argue that four developments contributed to the rise of Euroscepticism between 1991 and 2016: the ERM crisis; the increasing extent of European political integration; the Eurozone debt crisis; and mass immigration from Eastern Europe.
} 
Figure 2. Average Euroscepticism over time.

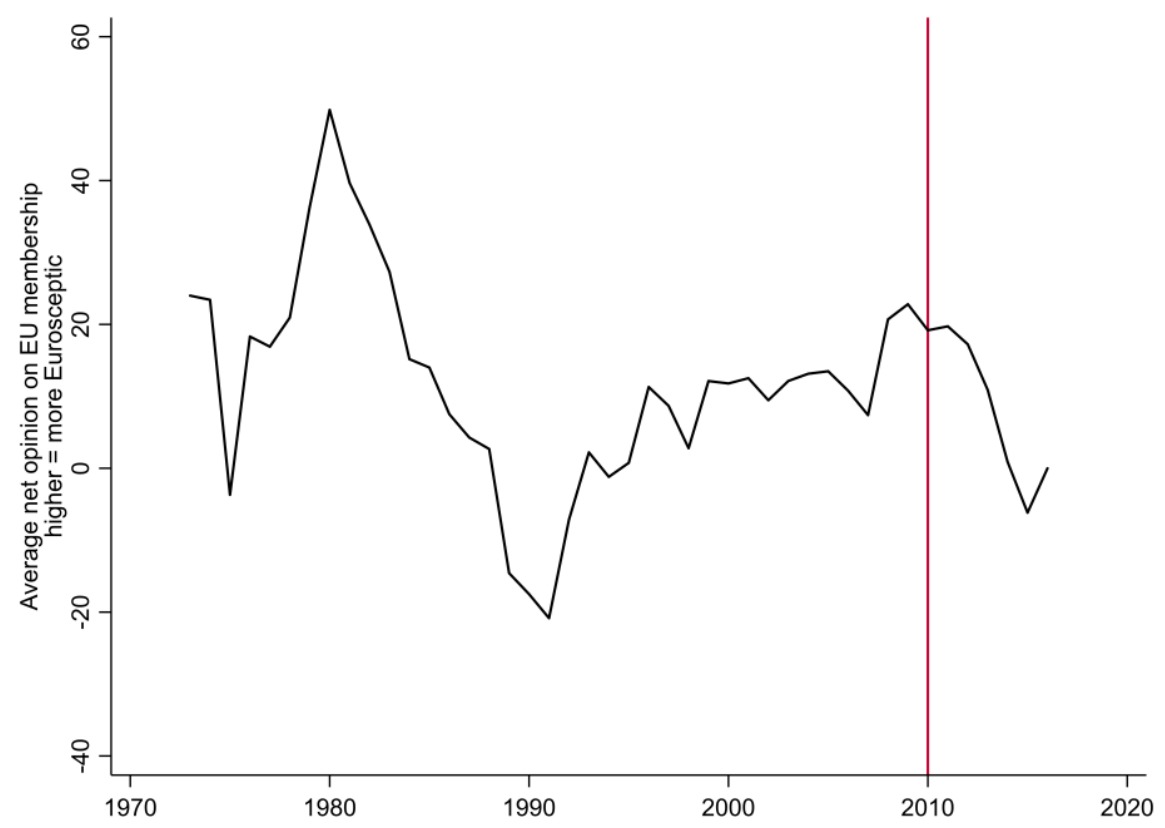

Notes: The red line indicates the beginning of austerity under the Conservative-led coalition government.

\section{Conclusion}

In an interesting recent paper, Fetzer (2018) argues that austerity may have led to an increase in the Leave vote share by up to 9.5 percentage points, an amount large enough to flip the referendum result. While Fetzer deserves credit for a highly creative and thorough analysis, his paper suffers from a number of important limitations. Austerity may not have had a causal impact on UKIP vote share at all, insofar as people with a latent propensity to vote UKIP were more likely to be affected by austerity, and the implementation of austerity happened to occur at the time that UKIP changed its electoral strategy toward winning over such people. Likewise, evidence from voting behaviour and opinion polls suggests that Leave voters were motivated by genuine Euroscpeticism and opposition to immigration, rather than by austerity-induced anti-establishment grievances. The present paper tested a corollary of Fetzer's argument, namely that the implementation of austerity measures should coincide with a rise in aggregate Euroscepticism. However, analyses of three separate polling series suggested the opposite, namely that aggregate Euroscepticism declined between 2010 and 2015. A plausible interpretation of this finding is that Euroscepticism peaked around the time of the Eurozone debt crisis, and was not strongly affected by austerity.

\section{Supporting Information}

Stata code and data are available at: https://osf.io/zbgt3/ 


\section{References}

Braun, D. \& Tausendpfund, M. (2014). The impact of the euro crisis on citizens' support for the European Union. Journal of European Integration, 36, 231-245.

Carl, N. (2018). CSI Brexit 4: Reasons Why People Voted Leave or Remain. Centre for Social Investigation, published online.

Carl, N., Dennison, J. \& Evans, G. (2018). European, but Not European Enough: An Explanation for Brexit. European Union Politics, forthcoming.

European Commission. (2018). Public opinion: Eurobarometer survey. European Commission, available online. European Parliament (2018) Parlemeter surveys. European Parliament, available online.

Evans, G. \& Carl, N. (2017). Chapter 5: Class and Politics. In Outhwaite, W. \& Turner, S. (eds.). The SAGE Handbook of Political Sociology. Thousand Oaks, CA: SAGE Publishing.

Fetzer, T. (2018). Did austerity cause Brexit? Warwick Economics Research Papers Series, July 2018, published online.

Ford, R. \& Goodwin, M. (2014). Revolt on the Right: Explaining Support for the Radical Right in Britain. Abingdon-on-Thames, UK: Routledge.

Ipsos MORI. (2016). European Union membership - trends. Ipsos MORI, 16 June 2016, published online.

Kellner, P. (2017). Why did so many voters switch parties between 2015 and 2017? New Statesman, 29 September, published online.

McKay, L. \& Bailey, J. (2018). Was Brexit really caused by austerity? Here's why we're not convinced. The Conversation, 3 September, published online.

Lai, H.W. (2018). [Comments on 'Had austerity not happened, Leave support could have been up to $10 \%$ lower']. LSE British Politics and Policy, 2-3 August, published online.

Prosser, C., Mellon, J. \& Green, J. (2016). What mattered most to you when deciding how to vote in the EU referendum? British Election Study, 11 July, published online.

UKIP. (2015). Believe in Britain: UKIP Manifesto 2015. UKIP, published online.

YouGov. (2016). EU Referendum Trackers: Voting Intention. YouGov, published online. 